\title{
PELATIHAN PEMBUATAN HAND SANITIZER BERSTANDAR WHO SEBAGAI UPAYA PENCEGAHAN COVID-19 DI DESA SRUNI KECAMATAN JENGGAWAH
}

\author{
Rohim \\ Progam Studi Ilmu Administrasi Negara \\ Sekolah Tinggi Ilmu Administrasi Pembangunan Jember \\ *Email: rohim.annida86@gmail.com
}

\begin{abstract}
ABSTRAK
Penyebaran Corona Virus Disease-19 (Covid-19) yang sangat masif membuat masyarakat harus ekstra menjaga kesehatan. Salah satu cara yang bisa dilakukan saat ini yaitu mencegah penyebaran Covid-19 dengan menerapkan protokol kesehatan yang ketat. Sebagai upaya pencegahan yaitu sering mencuci tangan dengan sabun cuci atau menggunakan hand sanitizer. Hand sanitizer menjadi salah satu opsi dikarenakan karena efektif dan efisien digunakan. Ketersediaan produk pencuci tangan (hand sanitizer) menjadi barang langka dan harganya cenderung lebih mahal dari harga normal, hal ini dikarenakan pembelian yang panik di tengah masyarakat. Berdasarkan fakta tersebut dipandang perlu melakukan pengabdian berupa pelatihan pembuatan hand sanitizer standard World Health Organization (WHO). pelatihan cara-cara pembuatan sediaan hand sanitizer, pengemasan yang baik dan pemasarannya bagi masyarakat di desa Sruni Kecamatan Jenggawah Kabupaten Jember. Tujuan akhir kegiatan ini yaitu masyarakat mampu meningkatkan keterampilan yang berdampak pada pencegahan Covid-19, mengurangi pengeluaran, dan meningkatkan pendapatan. Kata Kunci: Covid-19, Hand Sanitizer, Pelatihan
\end{abstract}




\section{Analisis Situasi}

Akhir tahun 2019 muncul sebuah varian virus baru yang berasal dari negara China tepatnya di kota Wuhan, virus tersebut dikenal dengan nama Covid-19. Virus ini berawal dari kasus lokal, kemudian Covid-19 menyebar ke seluruh dunia silih berganti dengan cara penularan yang disebut kasus impor dari luar wilayah asal atau transmisi lokal antarpenduduk. Sejauh ini, berbagai peristiwa yang pertama kali terjadi berkaitan dengan Covid-19 agaknya belum memberikan gambaran utuh tentang virus (Helabumi,R. 2020).

Kesimpulan sejauh ini, analisis para ahli menduga bahwa Covid-19 lebih kuat bertahan hidup di daerah bersuhu rendah dan kering walaupun virus ini juga mewabah di negara-negara dengan kondisi suhu dan kelembaban udara yang sebaliknya.

Berdasarkan fakta diatas, virus ini sangat mengerikan karena menyebabkan kematian, tidak memandang usia, jenis kelamin batas wilayah negara karena penularannya lebih cepat daripada virus-virus yang ada selama ini seperti: flu burung, SARS dan lain-lain.

Berbagai macam jenis virus, bakteri dan jamur menempel pada badan khususnya tangan karena setiap setiap harinya melakukan kontak fisik dengan orang lain maupun benda. Untuk mencegah penyebaran bahkan penularan virus, bakteri dan jamur, salah satu cara yang paling tepat yaitu sering mencuci tangan dengan sabun dan air bersih yang mengalir. Jika air bersih tidak tersedia, dapat menggunakan sabun dan air yang tersedia. Namun dapat juga digunakan pembersih tangan berbasis alkohol untuk membersihkan tangan atau yang disebut hand sanitizer.

Cara membersihkan tangan dengan menggunakan bahan antiseptik dikenal sejak awal abad 19. Hand sanitizer menjadi pilihan masyarakat modern karena bisa digunakan dalam waktu yang efektif dan efisien, kapanpun dan dimanapun. Tuntutan zaman yang demikian mengharuskan manusia untuk menjaga kesehatannya agar terhindar dari penyakit yang dapat 
menghambat gerak dan mengurangi efisiensi waktunya (Wahyono, 2010).

\section{Landasan Teori}

\section{II.I Pengertian cuci tangan}

Mencuci tangan dilakukan sebelum dan sesudah melakukan tindakan keperawatan walaupun memakai sarung tangan dan alat pelindung diri lain. Tindakan ini untuk mengurangi mikroorganisme yang ada di tangan sehingga penyebaran infeksi dapat dikurangi (Nursalam dan Ninuk, 2007). Mencuci tangan adalah proses yang secara mekanik melepaskan kotoran dan debris dari kulit tangan dengan menggunakan sabun biasa dan air (Depkes RI, 2009). Menurut Susiati (2008), tujuan dilakukannya cuci tangan yaitu untuk mengangkat mikroorganisasi yang ada ditangan, membuat kondisi tangan steril sehingga infeksi silang bisa dicegah.

\section{II.II Indikator Cuci Tangan}

Menurut Himpunan Perawat Pengendali Infeksi Indonesia (HPPI) tahun 2010 waktu melakukan cuci tangan, adalah bila tangan kotor, saat tiba dan sebelum meningggalkan rumah sakit, sebelum dan sesudah melakukan tindakan, kontak dengan pasien, lingkungan pasien, sebelum dan sesudah menyiapkan makanan, serta sesudah kekamar mandi. 2 Indikator mencuci tangan digunakan dan harus dilakukan untuk antisipasi terjadinya perpindahan kuman melalui tangan (Depkes,2008) yaitu:

a. Sebelum melakukan tindakan, misalnya saat akan memeriksa (kontak langsung dengan klien), saat akan memakai sarung tangan bersih maupun steril, saat akan melakukan injeksi dan pemasangan infus.

b. Setelah melakukan tindakan, misalnya setelah memeriksa pasien, setelah memegang alat bekas pakai dan bahan yang terkontaminasi, setelah menyentuh selaput mukosa. WHO telah mengembangkan Moments untuk Kebersihan Tangan yaitu Five Moments for Hand Hygiene, yang telah diidentifikasi sebagai waktu kritis ketika kebersihan tangan harus dilakukan yaitu sebelum kontak dengan pasien, sebelum tindakan aseptik, setelah terpapar cairan tubuh pasien, setelah kontak dengan pasien, dan setelah kontak dengan lingkungan pasien 
(WHO, 2009). Dua dari lima momen untuk kebersihan tangan terjadi sebelum kontak. Indikasi "sebelum" momen ditujukan untuk mencegah risiko penularan mikroba untuk pasien. Tiga lainya terjadi setelah kontak, hal ini ditujukan untuk mencegah risiko transmisi mikroba ke petugas kesehatan perawatan dan lingkungan pasien. $10 \quad 3$ Berikut gambar 5 moment mencuci tangan: Gambar 2.1 Five Moments Hand Hygiene ( Sumber: WHO,2009).

Macam-macam cuci tangan Cuci tangan medis dibedakan menjadi 3 jenis yaitu: a. Cuci tangan sosial/mencuci tangan biasa : untuk menghilangkan kotoran dan mikroorganisme transien dari tangan dengan sabun atau detergen paling tidak selama 10 sampai 15 detik. 4 b. Cuci tangan prosedural/cuci tangan aseptik : untuk menghilangkan atau mematikan mikroorganisme transien, disebut juga antisepsi tangan, dilakukan dengan sabun antiseptik atau alkohol paling tidak selama 10 sampai 15 detik. c. Cuci tangan bedah/cuci tangan steril : proses menghilangkan atau mematikan mikroorganisme transien dan mengurangi mikroorganisme residen, dilakukan dengan larutan antiseptik dan diawali dengan menyikat paling tidak 120 detik.

Teknik mencuci tangan Teknik mencuci tangan biasa Teknik mencuci tangan biasa adalah membersihkan tangan dengan sabun dan air bersih yang mengalir atau yang disiramkan, biasanya digunakan sebelum dan sesudah melakukan tindakan yang tidak mempunyai risiko penularan penyakit. Peralatan yang dibutuhkan untuk mencuci tangan biasa adalah setiap wastafel dilengkapi dengan peralatan cuci tangan sesuai standar rumah sakit (misalnya kran air bertangkai panjang untuk mengalirkan air bersih, tempat sampah injak tertutup yang dilapisi kantung sampah medis atau kantung pembersih tangan yang berfungsi sebagai antiseptik, lotion tangan, serta di bawah plastik berwarna kuning untuk sampah yang terkontaminasi atau terinfeksi), alat pengering seperti tisu, lap tangan (hand towel), sarung tangan (gloves), sabun cair atau cairan wastefel terdapat alas kaki dari bahan handuk. 
Prosedur kerja cara mencuci tangan biasa adalah sebagai berikut : a. Melepaskan semua benda yang melekat pada daerah tangan, seperti cincin atau jam tangan. $5 \mathrm{~b}$. Mengatur posisi berdiri terhadap kran air agar memperoleh posisi yang nyaman. c. Membuka kran air dengan mengatur temperatur airnya. d. Menuangkan sabun cair ke telapak tangan. e. Melakukan gerakan tangan, dimulai dari meratakan sabun dengan kedua telapak tangan, kemudian kedua punggung telapak tangan saling menumpuk, bergantian, untuk membersihkan sela-sela jari. f. Membersihkan ujung-ujung kuku bergantian pada telapak tangan. g. Membersihkan kuku dan daerah sekitarnya dengan ibu jari secara bergantian, kemudian membersihkan ibu jari dan lengan secara bergantian. h. Membersihkan (membilas) tangan dengan air yang mengalir sampai bersih, sehingga tidak ada cairan sabun dengan ujung tangan menghadap ke bawah. i. Menutup kran air menggunakan siku, bukan dengan jari karena jari yang telah selesai kita cuci pada prinsipnya bersih. Hal yang perlu diingat setelah melakukan cuci tangan yaitu mengeringkan tangan dengan hand towel.

Enam Langkah Cuci Tangan a. Ratakan sabun dengan kedua telapak tangan. b. Gosokan punggung dan sela-sela jari tangan dengan tangan kanan dan sebaliknya. c. Gosokan kedua telapak tangan dan sela-sela jari. d. Jari-jari sisi dalam dari kedua tangan saling mengunci. 6 e. Kemudian gosok ibu jari kiri berputar dalam genggaman tangan kanan dan lakukan sebaliknya. f. Gosok dengan memutar ujung jari ditelapak tangan kiri dan sebaliknya.

Pengertian Kepatuhan 8 Kepatuhan secara umum didefinisikan sebagai tingkatan prilaku seseorang yang mendapatkan pengobatan, mengikuti diet dan atau melaksanakan gaya hidup sesuai dengan rekomendasi pemberi pelayanan kesehatan (WHO, 2003) Kepatuhan merupakan modal dasar seseorang berprilaku. Menurut Kelma (1958) dalam Sarwono (1997) dijelaskan bahwa perubahan sikap dan prilaku individu diawali dengan proses patuh, identifikasi, dan tahap terakhir berupa internalisasi dimana 
prilaku yang baru itu dianggap bernilai positif dan diintegrasikan dengan nilai - nilai lain dihidupnya. Pada awalnya seseorang patuh terhadap instruksi bukan dari kerelaannya sendiri tapi karena untuk menghindari hukuman atau mendapatkan imbalan yang dijanjikan, ini termasuk tahap kepatuhan dan ini bersifat sementara dan dilakukan selama ada pengawasan saja. Definisi kepatuhan adalah tingkat seseorang melaksanakan suatu cara atau berprilaku seseorang dengan apa yang disarankan atau dibebankan kepadanya.

Kepatuhan perawat adalah perilaku perawat sebagai seorang professional terhadap suatu anjuran, prosedur atau peraturan yang harus dilakukan atau ditaati (Setiadi, 2007). Ketidakpatuhan adalah perilaku yang dapat menimbulkan konflik yang dapat menghasilkan perasaan bersalah pada seseorang dimana perilaku ditujukan. Perilaku ini dapat berbentuk verbal dan nonverbal. Perilaku ini terbagi menjadi tiga jenis menurut Murphy dalam Swansburg (2000) yaitu: 9 a.
Competitive Bomber yang mudah menolak untuk bekerja. Orang ini sering menggerutu dengan bergumam dan dengan wajah yang cemberut dapat pergi meninggalkan manajer perawat atau tidak masuk kerja. b. Martyred Accomodator yang menggunakan kepatuhan palsu. Orang tipe ini dapat bekerja sama tetapi juga sambil melakukan ejekan, hinaan, mengeluh dan mengkritik untuk mendapatkan dukungan yang lainnya. c. Advoider yang bekerja dengan menghindarkan kesepakatan, berpartisipasi dan tidak berespon terhadap manajer perawat.

Sebelum mengadopsi kepatuhan baru didalam diri orang tersebut terjadi proses yang berurutan yaitu diawali dengan adanya kesadaran dimana orang tersebut menyadari dan mengetahui terhadap stimulasi (objek), kemudian timbul rasa tertarik, menimbang terhadap baik tidaknya stimulus tersebut bagi dirinya. Setelah itu mulai mencoba melakukan sesuatu yang dikehendaki, akhirnya menerima kepatuhan baru sesuai dengan pengetahuan, kesadaran dan sikapnya terhadap stimulus. 
Faktor-Faktor

yang

Mempengaruhi Kepatuhan a. Faktor Internal Beberapa faktor yang termasuk faktor internal: 1) Karakteristik perawat Karakteristik perawat merupakan ciri-ciri pribadi yang dimiliki seseorang yang pekerjaanya merawat klien sehat maupun sakit ( Adiwimarta, et.al 1999 dalam Kamus Besar Bahasa Indonesia). Karakteristik perawat meliputi variabel 10 demografi yaitu umur, jenis kelamin, ras, suku bangsa dan tingkat pendidikan (Smet,1997). Tingkat kepatuhan untuk melakukan Kewaspadaan Universal kususnya berkaitan dengan HIV/AIDS dipengaruhi oleh faktor individu meliputi jenis kelamin, jenis pekerjaan, profesi, lama kerja dan tingkat pendidikan, serta faktor psikologis meliputi sikap, ketegangan dalam suasana kerja, rasa takut dan persepsi terhadap risiko (Putri,2010).

2) Kemampuan

Kemampuan adalah bakat seseorang untuk melakukan tugas fisik atau mental. Kemampuan seseorang pada umumnya stabil. Kemampuan merupakan faktor yang dapat membedakan karyawan yang berkinerja tinggi dan yang berkinerja rendah. Kemampuan individu mempengaruhi karateristik pekerjaan, perilaku, tanggung jawab, pendidikan dan memiliki hubungan secara nyata terhadap kinerja pekerjaan (Ivancevich et al, 2007). Manajer harus berusaha menyesuaikan kemampuan dan keterampilan seseorang dengan kebutuhan pekerjaan. Proses penyesuaian ini penting karena tidak ada kepemimpinan, motivasi, atau sumber daya organisasi yang dapat mengatasi kekurangan kemampuan dan keterampilan, meskipun beberapa keterampilan dapat diperbaiki melalui latihan atau pelatihan (Ivancevich et al, 2007).

Kemampuan adalah kapasitas seorang individu untuk mengerjakan berbagai tugas dalam pekerjaan yang meliputi kemampuan intelektual dan kemampuan fisik. Kemampuan intelektual mempunyai peran yang besar dalam pekerjaan yang rumit, sedangkan kemampuan fisik mempunyai peranan penting untuk melakukan 11 tugas yang menuntut stamina, kecekatan, kekuatan dan keterampilan (Suryoputri, 2011). 
Kemampuan seseorang bisa berbedabeda dalam pelaksanan mencuci tangan. Bagi perawat yang memiliki kemampuan melaksanakan akan cenderung patuh untuk melakukan cuci tangan ( Suryoputri, 2011 ). 3) Motivasi Motivasi adalah konsep yang menggambarkan kondisi instrinsik yang merangsang perilaku tertentu, dan respon instrinsik yang menampakkan perilaku manusia. Respon instrinsik ditopang oleh sumber energi, yang disebut motif yang dapat diartikan sebagai kebutuhan, keinginan, atau dorongan.

Motivasi diukur dengan perilaku yang dapat diobservasi dan dicatat (Swansburg, 2000). Motivasi dapat mempengaruhi seseorang untuk melaksanakan suatu pekerjaan yang menjadi tugas dan tanggung jawabnya. Motivasi adalah daya penggerak didalam diri orang untuk melakukan aktivitas tertentu demi mencapai suatu tujuan tertentu (Hamzah, 2008). Motivasi adalah rangsangan, dorongan dan ataupun pembangkit tenaga yang dimiliki seseorang atau sekelompok masyarakat yang mau berbuat dan bekerja sama secara optimal melaksanakan sesuatu yang telah direncanakan untuk mencapai tujuan yang telah ditetapkan ( Suryoputri, 2011). Maslow menyatakan bahwa motivasi didasarkan pada teori holistik dinamis yang berdasarkan tingkat kebutuhan manusia. Individu akan lebih puas bila kebutuhan fisiologis telah terpenuhi dan apabila kebutuhan tersebut tercapai maka individu tersebut tidak perlu dimotivasi. Tingkat kebutuhan yang paling mempengaruhi motivasi adalah tingkat kebutuhan aktualisasi diri. Aktualisasi diri merupakan 12 upaya individu tersebut untuk menjadi seseorang yang seharusnya (Ivancevich et al, 2007).

Motivasi dibedakan menjadi dua macam yaitu motivasi intrinsik timbulnya suatu proses yang ada didalam diri individu sendiri, dan motivasi ekstrinsik timbulnya karena adanya rangsangan dari luar individu. Fungsi dari motivasi dalam hubungannya dengan perilaku adalah sebagai penggerak untuk mendorong manusia bertindak menuju kearah perwujudan suatu tujuan (Hamzah,2008). Karakteristik umum 
dari motivasi adalah tingkah laku yang bermotivasi digerakan dimana pendorongnya kebutuhan dasar, memberi arah, menimbulkan intensitas bertindak, efektif, dan merupakan kunci untuk pemuas kebutuhan (Hamzah, 2008).

Menurut Notoatmodjo (2010) untuk meningkatkan motivasi seseorang ada dua metode, yaitu metode langsung dengan pemberian materi atau non materi secara langsung untuk memenuhi kebutuhan misalnya memberikan bonus atau hadiah, dan metoda tidak langsung berupa fasilitas atau saran dalam upaya meningkatkan motivasi dalam mencuci tangan. 4) Persepsi Persepsi setiap orang kususnya perawat tentang pelaksanan cuci tangan akan diterima, dimaknai, dan diingat secara selektif sehingga kepatuhan perawat dalam pelaksanan akan berbeda ( Suryoputri, 2011). 5) Pengetahuan Menurut Notoatmojo (2007) pengetahuan adalah hasil tahu seseorang terhadap objek melalui indera yang dimilikinya (mata, hidung, telinga, pengecap, peraba). 13 Pengetahuan orang terhadap objek mempunyai intensitas atau tingkat yang berbeda-beda yang dapat dibagi kedalam enam tingkat pengetahuan yaitu: (a) Tahu merupakan tingkat pengetahuan yang paling rendah. Tahu artinya dapat mengingat atau mengingat kembali suatu materi yang telah dipelajari sebelumnya.

Ukuran bahwa seseorang itu tahu, adalah dapat menyebutkan, menguraikan, mendefenisikan dan menyatakan. (b) Memahami, artinya kemampuan untuk menjelaskan dan menginterpretasikan dengan benar tentang objek yang diketahui dengan memberikan contoh dam menyimpulkan. (c) Penerapan, yaitu kemampuan untuk menggunakan atau mengaplikasikan materi yang telah dipelajari pada situasi dan kondisi nyata. (d) Analisis artinya adalah kemampuan untuk menguraikan objek ke dalam bagianbagian lebih kecil, tetapi masih di dalam suatu struktur objek tersebut dan masih terkait satu sama lain. (e) Sintesis, yaitu suatu kemampuan untuk menghubungkan bagianbagian di dalam suatu bentuk keseluruhan yang baru. (f) Evaluasi, yaitu kemampuan untuk melakukan 
penilaian terhadap suatu objek. Evaluasi dapat menggunakan kriteria yang telah ada atau disusun sendiri. Pengetahuan dapat diukur dengan wawancara atau angket yang menyatakan tentang isi materi yang ingin diukur dari responden (Notoatmodjo, 2007).

Faktor-faktor yang mempengaruhi tingkat pengetahuan menurut Notoatmodjo (2010), meliputi : (a) Tingkat pendidikan 14 Semakin tinggi tingkat pendidikan maka seseorang akan mudah menerima informasi sehingga makin banyak juga pengetahuan yang dimilikinya, sebaliknya pendidikan yang kurang akan menghambat perkembangan sikap seseorang terhadap nilai-nilai baru yang diperkenalkan. (b) Pengalaman Sesuatu yang pernah dialami seseorang akan menambah pengetahuan tentang sesuatu yang bersifat non formal. (c) Sumber informasi Orang yang memiliki sumber informasi yang lebih banyak akan memiliki pengetahuan yang lebih banyak pula. (d) Lingkungan Dalam lingkungan seseorang akan memperoleh pengalaman yang akan berpengaruh pada cara berpikir, dimana seseorang akan mempelajari hal-hal yang baik dan juga hal-hal yang buruk tergantung pada sifat kelompoknya. (e) Sosial Ekonomi Tingkat sosial ekonomi yang rendah menyebabkan keterbatasan biaya untuk menempuh pendidikan, sehingga pengetahuan pun rendah. (f) Umur Bertambahnya umur seseorang dapat berpengaruh pada bertambahnya pengetahuan yang diperolehnya, akan tetapi pada umurumur tertentu (usia lanjut) kemampuan penerimaan atau mengingat sesuatu pengetahuan akan berkurang. 15

Menurut Notoatmodjo (2010) pengetahuan dibagi menjadi tiga yaitu pengetahuan baik (skor 76$100 \%$ ), pengetahuan cukup (skor 56$75 \%$ ), pengetahuan kurang (skor 055\%). 6) Sikap Sikap merupakan penentu dari perilaku karena keduanya berhubungan dengan persepsi, kepribadian, perasaan, dan motivasi. Sikap merupakan keadaan mental yang dipelajari dan diorganisasikan melalui pengalaman, menghasilkan pengaruh spesifik pada respon seseorang terhadap orang 
lain, objek, situasi yang berhubungan. Sikap menentukan pandangan awal seseorang terhadap pekerjaan dan tingkat kesesuaian antara individu dan organisasi (Ivancevich et al, 2007). Sikap mempunyai tingkat berdasarkan intensitas yang menurut Notoatmodjo (2007) terdiri dari menerima, menanggapi, menghargai, bertanggung jawab. Sikap juga dapat dibentuk melalui pengalaman pribadi, pengaruh orang lain yang dianggap penting, pengaruh kebudayaan, media massa, lembaga pendidikan dan agama, dan faktor emosional.

Untuk mendapat nilai presentase dari nilai sikap responden, dapat digunakan rumus : Nilai persentasi responden $=$ Nilai jawaban responden x 100\% Nilai maksimal Menurut Sunaryo (2004), sikap dikatakan negatif apabila mendapat nilai $0-50 \%$ dan sikap dikatakan positif apabila mendapat nilai 51100\%. b. Faktor Eksternal Beberapa faktor yang termasuk faktor eksternal antara lain: 16 1) Karakteristik Organisasi Keadaan dari organisasi dan struktur organisasi ditentukan oleh filosofi dari manajer organisasi tersebut. Keadaan organisasi dan struktur organisasi akan memotivasi atau gagal memotivasi perawat profesional untuk berpartisipasi pada tingkatan yang konsisten sesuai dengan tujuan (Swansburg, 2000).

Ting dan Yuan (1997 dalam Subyantoro, 2009) berpendapat bahwa karakteristik organisasi meliputi komitmen organisasi dan hubungan antara teman sekerja dan supervisor yang akan berpengaruh terhadap kepuasan kerja dan perilaku individu. 2) Karakteristik Kelompok Kelompok adalah unit komunitas yang terdiri dari dua orang atau lebih yang memiliki suatu kesatuan tujuan dan pemikiran serta integritas antar anggota yang kuat. Karakteristik kelompok adalah adanya interaksi, adanya struktur, kebersamaan, adanya tujuan, ada suasana kelompok, dan adanya dinamika interdependensi (Suryoputri, 2011). Anggota kelompok melaksanakan peran tugas, peran pembentukan, pemeliharaan kelompok, dan peran individu. Anggota melaksanakan hal ini melalui hubungan interpersonal. Tekanan dari kelompok sangat 
mempengaruhi hubungan

interpersonal dan tingkat kepatuhan individu karena individu terpaksa mengalah dan mengikuti perilaku mayoritas kelompok meskipun sebenarnya individu tersebut tidak menyetujuinya (Suryoputri, 2011). 3) Karakteristik Pekerjaan Karakteristik pekerjaan akan memberikan motivasi bagi karyawan untuk lebih bekerja dengan giat dan untuk menumbuhkan semangat kerja yang lebih 17 produktif. Karakteristik pekerjaan adalah proses membuat pekerjaan akan lebih berarti, menarik dan menantang sehingga dapat mencegah seseorang dari kebosanan dan aktivitas pekerjaan yang monoton sehingga pekerjaan terlihat lebih bervariasi. Karakteristik pekerjaan adalah sifat yang berbeda antara jenis pekerjaan yang satu dengan yang lainnya, yang bersifat khusus dan merupakan inti pekerjaan yang berisikan sifat-sifat tugas yang ada di dalam semua pekerjaan, serta dirasakan oleh para pekerja sehingga mempengaruhi sikap atau perilaku terhadap pekerjaannya (Suryoputri, 2011). 4) Karakteristik Lingkungan Apabila perawat harus bekerja dalam lingkungan yang terbatas dan berinteraksi secara konstan dengan staf lain, pengunjung, dan tenaga kesehatan lain. Kondisi seperti ini yang dapat menurunkan motivasi perawat terhadap pekerjaannya, dapat menyebabkan stress, dan menimbulkan kepenatan (Swansburg, 2000). 5) Pola komunikasi Pola komunikasi dengan profesi lain yang dilakukan oleh perawat akan mempengaruhi tingkat kepatuhannya dalam melaksanakan tindakan.

Aspek dalam komunikasi ini adalah ketidakpuasan terhadap hubungan emosional, ketidak puasa terhadap pendelegasia maupun kolaborasi yang diberikan (Suryoputri, 2011). 6) Keyakinan Smet 1994 mengatakan bahwa keyakinaan tentang kesehatan atau perawatan dalam system pelayanan kesehatan mempengaruhi kepatuhan perawat dalam melaksanakan peran dan fungsinya. 7) Dukungan sosial 18 Dukung sosial menurut Smet 1994 berpengaruh terhadap kepatuhan seseorang. Variabel sosial yang mempengaruhi kepatuhan perawat adalah dukungan sosial dari 
komunitas internal perawat, petugas kesehatan lain, dukungan dari pimpinan pelayanan kesehatan serta keperawatan. Dukungan sosial adalah kenyamanan, perhatian,penghargaan, maupun bantuan dalam bentuk lainnya yang diterima individu dari orang lain ataupun kelompok (Sarafino, 2002).

Bentuk dukungan sosial (Sarafino,2002) ada lima yaitu (a) Dukungan emosi terdiri dari ekspresi seperti perhatian,empati, yang menyebabkan penerima dukungan merasa tentram, merasa dicintai, merasa dimiliki, member bantuan dalam bentuk semangat.

Dukungan penghargaan memberikan penghargaan positif terhadap seseorang, dukungan ini menyebabkan individu merasa bernilai. Dukungan ini berguna ketika individu mengalami stress karena tuntutan tugas yang lebih besar dari kemampuan yang dimiliki. (c) Dukungan instrument berupa bantuan secara langsung dan nyata seperti penyediaan sarana dan prasarana. (d) Dukungan informasi terdiri dari arahan, saran ataupun penilaian tentang bagaimana melakukan sesuatu. (e) Dukungan kelompok dukungan yang dapat menyebabkan individu merasa bahwa dirinya merupakan bagian dari suatu kelompok. 19 Tingkat kepatuhan untuk melakukan Kewaspadaan Uviversal kususnya berkaitan dengan HIV / AIDS dipengaruhi oleh faktor organisasi, suasana lingkungan kerja yang aman, dukungan dari rekan kerja, dan pelatihan (Putri 2010). Suryoputri, (2011) faktor yang berpengaruh terhadap kepatuhan : 1) Tidak adanya fasititas atau tempat untuk cuci tangan. 2) Waktu yang digunakan untuk cuci tangan. 3) Kondisi pasien. 4) Efek bahan cuci tangan terhadap kulit

\section{Pengertian Hand Sanitizer}

Hand sanitizer merupakan pembersih tangan pengganti sabun yang bisa dipakai diluar rumah. Hand Sanitizer memiliki kemampuan antibakteri dalam menghambat hingga membunuh bakteri (Retnosari dan Isdiartuti, 2006). Menurut Diana (2012) terdapat dua hand sanitizer yaitu hand sanitizer gel dan hand sanitizer spray. Hand sanitizer gel merupakan pembersih tangan 
berbentuk gel yang berguna untuk membersihkan atau menghilangkan kuman pada tangan, mengandung bahan aktif alkohol 60\%. Hand sanitizer spray merupakan pembersih tangan berbentuk spray untuk membersihkan atau menghilangkan kuman pada tangan yang mengandung bahan aktif irgasan DP $300: 0,1 \%$ dan alkohol $60 \%$. Penelitian Diana (2012) menyatakan, hand sanitizer yang berbentuk cair atau spray lebih efektif dibandingkan hand sanitizer gel dalam menurunkan angka kuman pada tangan.

Banyak hand sanitizer yang berasal dari bahan alkohol atau etanol yang dicampurkan bersama dengan bahan pengental, misal karbomer, gliserin, dan menjadikannya serupa jelly, gel atau busa untuk mempermudah dalam penggunaannya. Gel ini mulai populer digunakan karena penggunaanya mudah dan praktis tanpa membutuhkan air dan sabun. Gel sanitasi ini menjadi alternatif yang nyaman bagi masyarakat. (Hapsari, 2015).
Adapun kelebihan hand sanitizer dapat membunuh kuman dalam waktu relatif cepat, karena mengandung senyawa alkohol (etanol, propanol, isopropanol) dengan konsentrasi $\pm 60 \%$ sampai $80 \%$ dan golongan fenol (klorheksidin, triklosan). Senyawa yang terkandung dalam hand sanitizer memiliki mekanisme kerja dengan cara mendenaturasi dan mengkoagulasi protein sel kuman (Aminah Asngad, dkk, 2018).

Alkohol sebagai disinfektan hanya mempunyai aktivitas bakterisidal saja, tetapi tidak terhadap virus dan jamur. Selain sebagai disinfektan, alkohol dalam Hand sanitizer dapat membantu melarutkan triklosan. Menurut hasil penelitian penelitian Rini (2018) bahwa antiseptik pada beberapa merk dengan kadar alkohol 60-70\% tanpa tambahan zat antibakteri lainnya memiliki sifat yang lebih polar, sehingga diameter daya hambat yang dihasilkan lebih besar pada bakteri Staphylococcus aureus. 
III. Identifikasi dan Perumusan

\section{Masalah}

Dari uraian di atas, muncul berbagai permasalahan sebagai berikut:

"Bagaimana Pelatihan Pembuatan Hand Sanitizer Berstandar WHO (World Health Organization) dalam mengantisipasi pencegahan penularan Covid-19?”.

\section{Tujuan Kegiatan}

Program "Pelatihan Pembuatan

Hand Sanitizer Berstandar WHO (World Health Organization)" memiliki tujuan yaitu sebagai berikut:

i. Memberikan pengetahuan, pemahaman, dan kesadaran kelompok sasaran di Desa Sruni tentang bahayanya penularan Covid-19.

ii. Memberikan pelatihan pembuatan hand sanitizer berstandard WHO sebagai upaya pencegahan dan penularan Covid-19.

iii. Memberikan pelatihan penjualan secara online melalui medsos dan market place.

\section{Manfaat Kegiatan}

Adapun manfaat dari pengabdian ini adalah sebagai berikut:

i. Masyarakat mengetahui, memahami dan sadar tentang bahayanya Covid-19 sehingga berdampak kepada masyarakat tentang pentingnya perilaku hidup bersih.

ii. Masyarakat bisa membuat hand sanitizer berstandard WHO sebagai upaya pencegahan penularan Covid19.

iii. Selain mendapatkan keterampilan membuat hand sanitizer sebagai upaya pencegahan penularan Covd-19 juga mampu sebagai sumber tambahan penghasilan dengan cara memasarkan produk tersebut maupun produk yang lainnya melalui online yaitu media sosial maupun market place.

\section{Kerangka Pemecahan Masalah Adanya virus Covid-19 yang melanda dibelahan dunia ini merusak}


tatanan hidup dari berbagai aspek kehidupan mulai dari kesehatan maupun permasalahan ekonomi yang menjadi masalah serius yang berdampak bagi kelangsungan suatu masyarakat bahkan negara. Penyebaran virus ini masih belum diketahui kapan akan berakhir, namun mampu dicegah dengan cara melakukan pola hidup baru atau dikenal dengan istilah new normal.

Dibutuhkan kesadaran dari semua pihak baik dari masyarakat, pelaku usaha, maupun pemerintah karena kesehatan dan perekonomian harus sama-sama berjalan. Sejauh ini setiap negara berlomba-lomba melakukan penelitian untuk menemukan vaksin agar mampu melawan virus Covid-19 ini. Sampai dengan saat ini semua negara maupun perusahaan farmasi melakukan uji klinis agar vaksin tersebut berhasil mencegah timbulnya korban lebih banyak lagi.

Sebelum ditemukannya vaksin tersebut, hal pentng yang dilakukan oleh individu, maupun masyarakat yaitu dengan cara melakukan pola hidup bersih dan menerapkan protokal kesehatan (prokes) yang ketat yaitu 4 M: Memakai Masker, Mencuci Tangan, Menjaga Jarak, dan Menghindari Kerumunan. Hal tersebut dilakukan guna pencegahan dan pengendalian Corona Virus Disease (COVID-19).

Khusus mencuci tangan jika dirumah dapat dilakukan dengan menggunakan sabun dan air mengalir, namun disaat kita diluar rumah tidak memungkinkan kita memakai air mengalir maupun sabun maka yang menjadi solusi alternatif yang dianjurkan oleh World Health Organization (WHO) yaitu menggunakan hand sanitizer.

Berdeasarkan fakta tersebut, kami selaku Dosen beserta mahasiswa Sekolah Tinggi Ilmu Administrasi (STIA) Pembangunan Jember dipandang perlu mewujudkan hal tersebut dengan cara melakukan pengabdian kepada masyarakat dengan cara memberikan pelatihan pembuatan hand sanitizer yang berbahan kimia sebagai salah satu tugas dosen maupun mahasiswa untuk mewujudkan Tridharma perguruan tinggi.

Dengan adanya pelatihan ini juga diharapkan bisa menularkan 
ilmu yang mereka dapat kepada para warga sekitar maupun masyarakat luas agar bisa membuat sendiri hand sanitizer sebagai bentuk rasa peduli dan kebersamaan melawan Covid-19 yang sedang melanda di dunia ini.

Selain pelatihan pembuatan hand sanitizer, masyarakat juga diajarkan pemasaran secara online yaitu media sosial dan market place.

\section{Khalayak Sasaran}

Kelompok sasaran saat melakukan pelatihan pembuatan hand sanitizer standard World Health Organization (WHO) yaitu organisasi non formal ibu-ibu rumah tangga yang disebut kelompok sholawatan yang dipimpin oleh Ibu Musyarofah beralamatkan di Dusun Krajan Desa Sruni Kecamatan Jenggawah.

\section{Metode Kegiatan}

Kegiatan ini diawali dengan survey lapangan terlebih dahulu, permohonan ijin kepada penanggung jawab wilayah, serta mengumpulkan warga setempat untuk pelaksanaan kegiatan pelatihan.

\author{
Materi : tata cara pembuatan hand \\ sanitizer sesuai standard \\ World \\ Health \\ Organization (WHO) dan \\ pemasaran melalui media \\ sosial dan market place. \\ Media : Video tata cara \\ pembuatan hand sanitizer \\ dilanjutkan praktek \\ pembuatan hand sanitizer \\ sesuai standard World \\ Health Organization \\ (WHO). \\ Metode : demostrasi produk serta \\ praktek pemasaran \\ melalui media sosial dan \\ market place. \\ Waktu : Minggu, 20 Desember \\ 2020 Pukul 11.00 WIB \\ s.d selesai.
}

\section{Evaluasi Kegiatan}

Evaluasi kegiatan ini dilakukan dengan pemantauan setelah pelaksanaan kegiatan pelatihan pembuatan hand sanitizer standard WHO dengan cara melakukan pelatihan kembali pada pertemuan atau perkumpulan sholawatan ibuibu yang dilaksanakan setiap seminggu sekali sampai dengan 
kelompok ini benar-benar mampu membuat sendiri maupun membuat secara masal untuk dijual.

\section{Daftar Pustaka}

Aminah Asngad, Aprilia Bagas R, Nopitasari. (2018). Kualitas Gel Pembersih Tangan (Handsanitizer) dari Ekstrak Batang Pisang dengan Penambahan Alkohol, Triklosan dan Gliserin yang Berbeda Dosisnya. Jurnal Bioeksperimen. Vol. 4 (2) Pp. 61-70.

Doi:

10.23917/bioeksperimen.v4i1 .2795

Diana, A. 2012. Pengaruh Desiminasi Dokter Kecil Tentang Penggunaan Hand Sanitizer Gel dan Spray Terhadap Penurunan Angka Kuman Tangan Siswa SDN Demakijo Gamping Sleman. Skripsi. Poltekkes Kemenkes Yogyakarta.

Hapsari, D. N. 2015. Pemanfaatan Ekstrak Daun Sirih (Piper Betle Linn) Sebagai Hand Sanitizer. Skripsi. Poltekkes Kemenkes Yogyakarta.

Helabumi,

$\mathrm{R}$. 2020. https://bebas.kompas.id/bacal riset/2020/04/18/rangkaianperistiwa-pertama-covid-19/. Diakses tanggal 21 Desember 2020 Pukul 21.43 WIB.

Retnosari dan Isadiartuti, D. 2006. Studi Efektivitas Sediaan Gel Antiseptik Tangan Ekstrak
Daun Sirih (Piper betle L.). Majalah farmasi Indonesia.

Rini, E. P., \& Nugraheni E. R. 2018. Uji Daya Hambat Berbagai Merek Handsanitizer Gel Terhadap Pertumbuhan Bakteri Escherichia coli dan Staphylococcus Aureus. Journal of Pharmaceutical Science and Clinical Research, 1(10), 18-26.

Wahyono, Hendro et al., 2010. Preventing Nosocomial Infections: Improving Compliance with Standard Precautions in An Indonesian Teaching Hospital. Journal of Hospital Infection 2006 Sep: 64(1): 36-43. 